\title{
Need Analyses of English Learning Material for Students' Diploma Degree of Mechanical Engineering at Institute Technology of Padang (ITP)
}

\author{
Okri Ronaldo ${ }^{1, *}$, M. Zaim ${ }^{1}$, Hamzah $^{1}$ \\ 1. English Education Study Program of Universitas Negeri Padang, Padang, Indonesia \\ *Corresponding Author. Email: okrironaldo90@gmail.com
}

\begin{abstract}
Need Analyses have a wide definition in educational system which is used as the first step to conduct curriculum, syllabus, teaching and learning material, and others. In this case, it focuses on finding primary data about English learning material for diploma degree students of Mechanical Engineering. By doing this study, researcher collected the information about the needs toward English teaching material which is divided into three types need analyses such as; Present Situation Analysis (PSA), Target Situation Analysis (TSA), and Learning Needs Analysis. It used multiple-methods where the data were collected by questionnaire and interview and analysed both of qualitative and quantitative. The participants of this research are 28 people of Diploma degree Students of mechanical engineering in ITP, an English lecturer who taught in mechanical engineering, and 2 mechanical lecturers at ITP. The result presented the ability and interest of students in English, objectives and conditions of the using English, and the English for Specific Purposes (ESP) as approach of learning material that the students' need for their future. In brief, learning material should consider all of the aspect that is found from the need analyses result in order to relate and be relevant for the learners. Thus, the learners will be motivated and enjoy the learning process because the learning material is appropriate with them.
\end{abstract}

Keywords: Need analyses, English for Specific Purposes, English for Mechanical Engineering

\section{INTRODUCTION}

\subsection{Research Background}

The development of English for Specific Purposes (ESP) has become an interesting field to be researched at the moment. ESP properly is seen not as any particular language product but as an approach toward language teaching which is connected by specific or certain reasons and purposes of learning, as Hutchinson and Waters [1] state that ESP must be seen as an approach of English Language Teaching not as a product of it. Then, Harding [2] explains ESP is designed to meet specific needs of the learners, makes use of the underlying methodology and activities of the learning language, and it is also centred on the language such as; grammar, lexical and register which put on the teaching material [p 6]. It describes strongly the importance of ESP in particular work and subject, such as; Nursing, Economic, Science, Automotive, Culinary, Tourism, Mechanical, and others.

Though, there are many particular works that touched by ESP, Mechanical is one of field that has development very fast and continuity since 1780 or Industrial revolution started. Thus, learning mechanical which refers to mechanical engineering can be a way to compete in this globalization era where it encompasses the generation an application of designing, production and use machines and tools, as Sanker, Hazarika, and Paulo [3] explain, mechanical engineering can be defined as the branch of engineering dealing with the design, construction, operation, and maintenance of machine.

The need of ESP in learning mechanical engineering has increased every day. This need expects to the lecturer who teach in English subject in mechanical engineering should be able to combine all of aspect in learning process such as; materials, students' ability, the needs of workplace, time, and environment. By using ESP, lecturers lead and guide the learner to comprehend English that convenient with the workplace of learners; mechanical engineering. It is supported by Dudley-Evans and John [4] who said ESP is a practical discipline with the main focus on helping learners to learn language based on their specific field. Implementing ESP into English learning process gives two main benefits. Firstly, it increases the ability and knowledge of learners toward mastering English in their specific skill. Secondly, it stimulates the learners to study English because ESP gives description of how important that language for their career in the future. 
Thinking of the importance of ESP, one of the key issues is the need analyses of teaching ESP in the university. Need analyses is the first step to implement the ESP. It uses to collect the information of course and its implementation. According to Basturkmen [5], need analysis is a way to investigate the perceptions of language needs of different group and have often revealed differing perceptions toward learning material. It deals with the meaning of need analysis as a step to prepare material in teaching and learning language. It is the means of establishing the how and what of a course. It is a continuous process since lecturer modifies the teaching for students in order to learn more. By this way, it actually shades into evaluation to establish the effectiveness of a course. Thus, it shows what lecturer prepares and determines while the teaching and learning process.

\subsection{Field, Area, and Scope of Research}

Compliance with other research in literature, this research stands to discipline of Applied Linguistic that has its specific field, area, and scope. This research can be categorized into primary research in the field of English for Specific Purposes (ESP) studies that consistent to explore the use of English in specific skill. Many various areas can be explored in ESP, as Dudley and John [4], mentioned ESP teacher and practitioners need to be aware in touch for ESP research like; need analysis, designing course, or writing teaching material need to be able to incorporate the finding of the research [p 15]. Hence, there are many similar topics of research that have been done by many experts and researchers; however, this research mainly focuses to explore the basic information for forwarding research in the future. To make this research concentrated, it should have specific scope and it is needed. Scope of this research is as a primary research that collects the information for the forward research in ESP and it is called need analysis.

\subsection{Review of Related Research}

Many researchers have been taken related studies with this research. In spite, they have done in different scope and area. It represents the interest toward the topic of this study. This situation gives the insight about the process of collecting information in need analysis, especially need analysis in ESP. Hou [6] conducted a research with the topic a need analysis of culinary art Majors' ESP Learning in Taiwan Context. It uses multiple methods and multiple sources in collecting the data. The result of the study showed that there are some significant differences between learning needs and target needs and it also proposed a curriculum design model based on its result. Hou [6] recommended an ESP curriculum design and teaching methodology for culinary arts majors in vocational school should be discussed.

Another though provoking research for need analysis also was done by Kumari and Rahman [7] presented study about a need analysis of underprivileged technical students at Indian school of Mines, Dhanbad, India. The purpose of their study is to identify and analyse the language needs of students studying a Bachelor of Technology degree programme (B.Tech) at Indian School Mine. The instrument used is questionnaires and the result of need analysis showed that, though, the participants have taken learning English at primary, secondary, and higher secondary levels, the learners still have lack of mastering English. Then, Kumari and Bajibur [7] also gave recommendations for enhancing the present syllabus and making it more learner-centred.

Furthermore, Chovancova [8], presented a study about need analysis and ESP course design: self-perception of language needs among pre-service students. This study emphasizes the present and target situation analysis with considering the necessities, wants, and lack, as Hutchinson and Waters [1] explain that need analysis in ESP has purpose to investigate the necessities, wants, and lacks of the learners in order to find the valid information for the ESP course. The purpose of the study tries to find the situation of learners who joining in pre-service programme about learning English by asking their expectation and perspective. The result of this study pointed that although pre-service students have vague ideas about the use of English in their future job, course instructor should consider their needs and wants. It means course instructor is expected to obtain the information from professional and former graduates as well because that will enable them to address the actual target situation most effectively.

The next related research was conducted by Chostelidou [9] that reported a research with entitle, a need analysis approach to ESP syllabus design in Greek tertiary education: a descriptive account of students' needs. The aim is to identify the need of target group of learners and introduce needs-based course design. It uses a multiple-method approach by using interview and questionnaire which included close and open-questionnaires. Then the finding of the study revealed the need for the development of a highly specific ESP language course with mainly focus on target discipline, accountancy. It showed that need analysis gives the concentrated to the learning process.

The latest related research in this article comes from Saragih [10] that conducted a research with the title, designing ESP material for nursing students based on need analysis. Its aim is to explore the learning need of nursing students, and then designing ESP material for nurses based on the need analysis result. In his study, he categorized need analyses into several types. The types have been explained by Lowe [11], he categorized need analysis into several types, such as; Target situation analysis, Present situation analysis, Deficiency analysis, Strategy analysis, Constraint analysis, Pedagogic need analysis, and Subjective need analysis. Saragih [10] found the need for setting up a language course with the clear focus on English for Specific Purposes and on the target discipline. Then, the information 
is used as a basic data to design the teaching material for nursing students.

From the related researches above, it can be concluded that investigating the need analysis have been an interesting topic that done by many researchers in literature. Need analysis has become the fundamental step to continue the forward researches that categorized into developmental research. In other word, its result is used as basic data to conduct the next research. According to Purpora and Graziano-King [12] and Hou [6] added Means Analysis as a type of need analysis beside of Target situation analysis, Present situation analysis, and Learning need analysis where Hutchinson and Waters [1] and Dudley and John [4], they mention there are three essential types of need analysis such as; Target situation Analysis (TSA), Present situation Analysis (PSA), and Learning situation Analysis (LSA). Though, there are several types of need analysis in ESP, the researcher just tend to three type of need analysis in this research including Present situation analysis, Target situation analysis and Learning need analysis that represent the necessities, wants, and necessities of the learners.

\subsection{Research Questions}

Research question is the way to tend the research topic statements. According to Gay, Mills, and Airasian [12], developing research questions breathes life into the research topic statement [p 67]. In other words, research question and the data collection strategies have a direct connection. By the research question, the researcher can find what the objective of the research topic and create an appropriate instrument by considering the research question and the topic. Additionally, Mackey and Gass [13] mentioned that research questions need to be interesting in the sense that they address current issues; at the same time, they need to be sufficiently narrow and constrained so that they can be answered. Broad questions can be difficult if not impossible to address without breaking them down into smaller answerable questions. Referring to the experts' explanation above, the researcher formulates three research questions in this research that has done in Mechanical engineering department in Institute Technology of Padang (ITP) as follow;

a. How is the Present situation Analysis of Mechanical engineering students?

b. What is the Target situation Analysis of Mechanical engineering?

c. What is the Learning need analysis of Mechanical engineering students?

The three research questions have given the prior data to conduct an ESP Teaching material for Mechanical Engineering Students and they are part of need analysis of ESP approach.

\section{METHODS}

\subsection{Research Design}

Like many other related researches about need analysis in the previous explanation, this study used multiple-methods to conduct a result at the end of the study, as Long [14] explains the methods used in taking need analysis can be both of existed methods; quantitatively and qualitatively. The use of multiple-method is to gain the specific information that related to the needs of the learners. In addition, choosing this method is also influenced by the use of multiple-instruments and multiple-sources that should be analysed qualitatively and quantitatively. Both of the reasons support the implementation the method in this study.

\subsection{Research Instruments}

This research used two different instruments in collecting the information related to the need analysis of learning English for mechanical engineering students in Institute Technology of Padang. Instrument includes to the main key of a study [12]. These instruments are questionnaires and interview. They were used to answer three research questions that conducted as before. They are Present situation analysis, Target situation analysis, and Learning needs analysis [1]. Present situation analysis can be defined as the way to find the strengths and weaknesses in language, skill, and learning experiences. Then, target situation analysis has purpose to gather the information of learning objective and what the students achieved in the learning. The last, learning needs analysis includes the process-oriented needs of learning. Therefore, the instruments have been divided in three parts.

Questionnaire that conducted was adapted and synchronized in order to gather the trustworthy information toward the needs of learners in learning English for mechanical engineering. In other word, it has certain instruction for each item the questionnaires, such as; the participants can give respond more than one option, and then they are only allowed to choose one option in another item. The purpose is to gather the specific information about the real situation occurred.

\subsection{Respondents}

In this research, respondents are the sources of data, as Mukhayar [15] mentioned implicitly, respondents are group of people who give the information related to the topic of the research. Like the previous description, this study used multiple-sources of data. Therefore, there are several clarifications of respondents; they are mechanical engineering students, Mechanical lecturers, and English lecturer who teach in the mechanical engineering. The number of mechanical engineering students is 28 people who take apart in diploma degree programme in academic year 2017/2018, 2 mechanical engineering lecturers and an English lecturer. 


\subsection{Technique of Data Collection}

In practice, the data were collected by using two kinds of instruments; questionnaires and interview. The questionnaires have distributed to the 28 learners. From the questionnaires, researcher has collected the information for three type of need analysis; present situation analysis, target situation analysis, and learning needs analysis. They only came from students' perspective about the needs of learners. To support and triangulate the data, researcher also took another instrument to another respondents; mechanical lecturer and English lecturer. Researcher interviewed them by using unstructured interview technique. The outline of interview is related to the tree type of need analysis above. Hence, the information that came from different sources can be compared and supported each other so that it can be valid information toward the need of learners in mechanical engineering.

\subsection{Technique of Data Analysis.}

The impact of using multiple-method in this study, the researcher expected to combine the data analysis quantitatively and qualitatively. The data from questionnaires have analysed by using formulation, as Riduwan [17], the researcher counted the frequency of the students' responses about the questionnaire by tabulated it used the following formula [p 89].

\subsection{Present situation Analysis}

This analysis has purposes to find out the condition of learners such as; their language course, experience of learning English. It estimates the strengths and weaknesses
Note: $\mathrm{P}=$ Percentage of students'

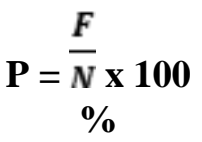
answer in the questionnaires $\mathrm{F}=$ Frequency of total score students' answer in the questionnaires $\mathrm{N}=$ Total Respondents

After getting the data based on the formulation, researcher synchronized the information with interviews' result from mechanical engineering and English lecturer. Thus, it can be valid information for need analysis where the data have been triangulated.

\section{FINDING AND DISCUSSION}

After collecting and analysing the data; measuring the percentage of questionnaires and learning the interview result, researcher got the findings of this research. The findings are presented in the form of percentages of questionnaires and then they are supported by some statements and information from lecturers. In addition, the findings are divided into three parts of need analysis related to the research questions.

in language [4]. Here, researcher gathered the information from three different sources; the students' themselves, mechanical lecturers, and English lecturer. The finding would be described as table below:

Table 1. Result of questionnaires number 1

\begin{tabular}{|l|c|c|c|c|c|}
\hline Item Questionnaires & $\begin{array}{c}\text { Strongly } \\
\text { Interesting }\end{array}$ & Interesting & $\begin{array}{c}\text { Not } \\
\text { Interesting }\end{array}$ & $\begin{array}{c}\text { Strongly Not } \\
\text { Interesting }\end{array}$ & $\mathrm{N}$ \\
\hline $\begin{array}{l}\text { Does English interest for } \\
\text { you? }\end{array}$ & $10.71 \%$ & $67.86 \%$ & $10.71 \%$ & $10.71 \%$ & 28 \\
\hline
\end{tabular}

This table showed that the students' interest toward learning English tends to high level. This data showed $67.86 \%$ of respondents mentioned that they agree English is interesting and $10.71 \%$ stated they strongly agree. Only
$21.42 \%$ of 28 respondents chooses disagree and strongly disagree. In other words, English is interesting for them. It also supported by interview's result from English lecturer where the students are active enough in learning process.

Table 2. Result of Questionnaire number 2

\begin{tabular}{|l|c|c|c|c|c|}
\hline Item Questionnaire & Never & $\leq 6$ Months & 6 Months to 1 Year & $\geq 1$ Year & N \\
\hline $\begin{array}{l}\text { Have you ever taken } \\
\text { English Course? }\end{array}$ & $78.57 \%$ & $10.71 \%$ & $10.71 \%$ & $0 \%$ & 28 \\
\hline
\end{tabular}

Although English is interesting for students, the different item has presented that most of students never take
English course before they continue their education to the college. It is about $78.57 \%$ of respondents' respond stand to 
never take an English course. Only $21.42 \%$ of respondents who took English course less than one year. Researcher could assume that the students' ability of English stand to lower of average.

Table 3. Result of Questionnaire number 3

\begin{tabular}{|l|c|c|c|c|c|}
\hline Item Questionnaire & Very Good & Good & Not Good & Worst & N \\
\hline $\begin{array}{l}\text { In your Perspective, How's } \\
\text { about your English today? }\end{array}$ & $3.57 \%$ & $17.86 \%$ & $57.14 \%$ & $21.43 \%$ & 28 \\
\hline
\end{tabular}

Like the description of table 2, this item of questionnaire asked the students opinion about their English ability in the moment. This data presented that most of the students' competencies of English are lack and weak where $57.14 \%$ of respondents. It showed that their English competencies are lack and weak. Then, $21.43 \%$ of respondents claimed their English ability is very bad.
Therefore, researcher could state that the students' ability in English tends to stay in Basic level and it should be considered in adapting learning material. It synchronized with the English lecturer mentioned that most of the students do not have good competencies in English. It can be seen from their exercise and task where they get difficulties to express a simple structure of English.

Table 4. Result of Questionnaire number 4

\begin{tabular}{|l|l|l|l|r|c|}
\hline Item Questionnaire & $\begin{array}{l}\text { Strongly } \\
\text { Agree }\end{array}$ & Agree & Disagree & $\begin{array}{l}\text { Strongly } \\
\text { Disagree }\end{array}$ & N \\
\hline $\begin{array}{l}\text { Do you agree that English is one of } \\
\text { supporting skill in your career? }\end{array}$ & $42.86 \%$ & $\begin{array}{l}53.57 \\
\%\end{array}$ & $3.57 \%$ & $0 \%$ & 28 \\
\hline
\end{tabular}

Table 4 showed that this items ask students' opinion about does English is one of supporting skill in career?. This data presented that the students choose $42.86 \%$ in strongly agree and $53.57 \%$ in Agree. It means that almost $100 \%$ students have the same opinion. In addition, English lecturer and mechanical engineering lecturer agreed that English competence is one of supporting skill that should be had by the learners. Therefore, the students should learn and understand English to support them in their career.

\subsection{Target situation Analysis}

This analysis determines the purpose of learners in learning English in their study. There are three items that relate to the objective of learner and the respondents could answer more than one option given. Each option was be formulated into one single definition. Therefore, a respondent could give two or more option that really suitable with the condition. The result of Target situation analysis is described as follow tables.

Table 5. Result of Questionnaire number 5

\begin{tabular}{|l|l|l|l|l|l|}
\hline Item Questionnaire & $\begin{array}{l}\text { For } \\
\text { Education }\end{array}$ & $\begin{array}{l}\text { For } \\
\text { Working }\end{array}$ & $\begin{array}{l}\text { For } \\
\text { Training }\end{array}$ & $\begin{array}{l}\text { For Specific } \\
\text { Purposes }\end{array}$ & $\mathrm{N}$ \\
\hline $\begin{array}{l}\text { What are the objectives of } \\
\text { learning English in your } \\
\text { study? }\end{array}$ & $71.43 \%$ & $78.57 \%$ & $14.29 \%$ & $21.43 \%$ & 28 \\
\hline
\end{tabular}

The questionnaire of table number 5 showed that the students prefer the objective in learning English is for working rather than others option, but the chosen for working is not quite different result for education, it is about $71.43 \%$ while the result for working about $78.57 \%$. it means that more of the students though that objective in learning English are for working and education. The result can be influenced of their though that English as a one of competencies should be mastered in order to elevate their career in the future. Mechanical lecturers also mention that English must be mastered by the mechanical engineering because most of guideline book for engineering used English as language of instruction. It means they enrich their insight whether they could master and communicate effectively in English. The, $14.29 \%$ of respondents stood to mention 'Training' as an objectives and $21.43 \%$ of respondents agreed to state for specific objectives. 
Table 6. Result of Questionnaire number 6

\begin{tabular}{|l|l|l|l|l|l|}
\hline Item Questionnaire & Listening & Speaking & Reading & Writing & $\mathrm{N}$ \\
\hline $\begin{array}{l}\text { In your opinion, what language } \\
\text { skills do you need that support } \\
\text { your specific skill? }\end{array}$ & $60.71 \%$ & $57.14 \%$ & $42.86 \%$ & $32.14 \%$ & 28 \\
\hline
\end{tabular}

The next item, researcher explained the result of language skill that really needed by the students in their career. Listening is the option that chosen by the respondent around $60.71 \%$. In the second one is speaking with $57.14 \%$ then followed by Reading $42,86 \%$ and writing $32.14 \%$. In the other hand, the result of mechanical engineering lecturer sated that reading is the main skill that give a large benefit to the learners' specific skill. Because learners expect to read the journals and books about machine that using English as the instructional media.

Table 7. Result of Questionnaire number 7

\begin{tabular}{|l|c|l|l|l|l|}
\hline Item Questionnaire & $\begin{array}{l}\text { Sharing } \\
\text { information with } \\
\text { foreign people }\end{array}$ & $\begin{array}{l}\text { Academic } \\
\text { Interaction }\end{array}$ & $\begin{array}{l}\text { Reading English } \\
\text { Books and } \\
\text { Journal }\end{array}$ & $\begin{array}{l}\text { Interact with } \\
\text { experts }\end{array}$ & $\mathrm{N}$ \\
\hline $\begin{array}{l}\text { What is situation that } \\
\text { English you need? }\end{array}$ & $50 \%$ & $25 \%$ & $57.14 \%$ & $32.14 \%$ & 28 \\
\hline
\end{tabular}

The last item of Target situation Analysis asks about the situation of the learners that use English. The data pointed that 'reading English books and journal' become the dominant choice of the learners. It is about $57.14 \%$, and the second one is to 'share information with foreign people. Then, it was followed by 'interact with experts, around $32.14 \%$ and the last one 'academic interaction', it was about $25 \%$. When we compared with the result of table 6 , they showed the suitable result where language skills that dominant chosen by the respondent valid with the respondents' respond the table 7 .

\subsection{Learning Needs Analysis}

Learning needs analysis focuses to find out the language learning information about the effective ways of learning the language and its skill. In ESP, learning need analysis refers to the process of matching the environment of students' specific skill with the language learning process. Both of them should be suitable in order to motivate the learners in learning language. Here, the data of learning need analysis were analysed generally because the questionnaire has been set to close-ended questionnaires. It would present the process of learning related to implement the ESP into the learning process of English subject in the mechanical engineering department at Institute Technology of Padang (ITP). Each item of questionnaire is asked the students' perspective on English learning process.

Table 8. Result of Learning Needs Analysis Questionnaire

\begin{tabular}{|r|l|c|c|c|c|c|}
\hline No & Item Questionnaires & $\begin{array}{c}\text { Strongly } \\
\text { Agree }\end{array}$ & Agree & Disagree & $\begin{array}{c}\text { Strongly } \\
\text { Disagree }\end{array}$ & $\mathbf{N}$ \\
\hline 1 & $\begin{array}{l}\text { As Mechanical Engineering student, } \\
\text { what is your opinion about English } \\
\text { ability is a skill that should be belong? }\end{array}$ & $28.57 \%$ & $67.68 \%$ & $3.75 \%$ & $0 \%$ & 28 \\
\hline 2 & $\begin{array}{l}\text { English ability could help me in } \\
\text { elevating my career }\end{array}$ & $35.71 \%$ & $64.29 \%$ & $0 \%$ & $0 \%$ & 28 \\
\hline 3 & $\begin{array}{l}\text { To increase my English ability, I do } \\
\text { extra study outside of classroom } \\
\text { independently }\end{array}$ & $7.14 \%$ & $57.14 \%$ & $32.14 \%$ & $3.57 \%$ & 28 \\
\hline 4 & Topic of learning English should be & $39.29 \%$ & $53.57 \%$ & $7.14 \%$ & $0 \%$ & 28 \\
\hline
\end{tabular}




\begin{tabular}{|c|c|c|c|c|c|c|}
\hline & uitable with my specific skill & & & & & \\
\hline 5 & $\begin{array}{l}\text { English learning material should be } \\
\text { appropriate with my specific skill }\end{array}$ & $28.57 \%$ & $50 \%$ & 21.43 & $0 \%$ & 28 \\
\hline 6 & $\begin{array}{l}\text { English learning material that relate to } \\
\text { my specific skill stimulates my } \\
\text { learning motivation }\end{array}$ & $39.29 \%$ & $53.57 \%$ & $7.14 \%$ & $0 \%$ & 28 \\
\hline 7 & $\begin{array}{l}\text { Teaching media should be variety and } \\
\text { suitable with the topic and material } \\
\text { taught }\end{array}$ & $42.86 \%$ & $53.57 \%$ & $3.57 \%$ & $0 \%$ & 28 \\
\hline 8 & $\begin{array}{l}\text { In learning process, you need } \\
\text { activities that consisted of cognitive, } \\
\text { affective, and psycho-motor aspect }\end{array}$ & $21.43 \%$ & $67.86 \%$ & $10.71 \%$ & $0 \%$ & 28 \\
\hline 9 & $\begin{array}{l}\text { Exercise as evaluation should be } \\
\text { given in every topic of learning }\end{array}$ & $21.43 \%$ & $67.86 \%$ & $3.57 \%$ & $7.14 \%$ & 28 \\
\hline & $\overline{\mathbf{X}}$ & $29.37 \%$ & $59,52 \%$ & $9.92 \%$ & $1.19 \%$ & 28 \\
\hline
\end{tabular}

Based on the average result of learning needs analysis above, researcher could state that the students have comprehended well the advantages of using ESP approach in their learning language. The data presented that $59.52 \%$ of respondents agree to implement the teaching material proposed by the researcher and $29.37 \%$ of respondents claimed they were strongly agree. When the results combine both of them, the researcher could conclude that $88.89 \%$ of respondents expected to implement the material proposed by the researcher. Only $11.11 \%$ of respondents have disagreed to implement it.

\section{CONCLUSION AND SUGGESTION}

From this research, researcher informs the need analysis of teaching material for mechanical engineering students at ITP has been concluded. Each type of analysis has presented the data as a consideration in adapting teaching material. The first type, present situation analysis, described two main informations; students have a high interesting in learning English and they know English is an important skill that should be mastered; most of the students have lack of

\section{REFERENCES}

[1] Hutchinson T, Waters A 1987 English for Specific Purposes A Learning Centered Approach (New York: Cambridge University Press)

[2] Harding K 2007 English for Specific Purposes (New York: Oxford University Press)

[3] Dixit US, Hazarika M, Davim JP A Brief Story of Mechanical Engineering (New York:Springer)
English ability. Thus, it should be considered when creating the teaching material. The second type, target situation analysis, also mentioned two crucial points; objectives of learning English in their study. These are for working and studying. Then, language skill that dominant used for their specific skill, they are reading listening and speaking. The last type of this study, learning needs analysis, showed that the importance of implementing the ESP approach into teaching material. Therefore, each finding of this study should be considered during conducting the teaching material in order to match and suitable with the learners.

\section{ACKNOWLEDGMENTS}

In this occasion, we want to give a great appreciation for the principal of Institute Technology of Padang who permits me in conducting this study. Then, to our beloved family who supporting and funding me in doing this study.

[4] Dudley-Evans T, John MJST 2007 Developments in English for Specific Purposes A Multi-Disciplinary Approach. (New York: Cambridge University Press)

[5] Basturkmen H 2010 Developing Courses in English for Specific Purposes (New York: Palgrave Macmillan) 
[6] Hou H 2013 A Need Analysis of Culinary Arts Majors' ESP Learning in Taiwan's Context. The ASIAN ESP Journal 9 4-33

[7] Kumari P, Rahman MdM 2012 A Needs Analysis of Underprivileged Technical Students at India School of Mines, Dhanbad, India The ASIAN ESP Journal 8 93-124

[8] Chovancova B 2014 Need Analysis and ESP Course Design: Self Perception of Language Needs Among Preservice Students Studies in Logic, Grammar, and Rethoric 38. DOI: https://doi.org/10.2478/slgr-2014-0031

[9] Chostelidou D 2010 A Need Analysis Approach to ESP Syllabus Design in Greek Tertiary Education: A Descriptive Account of Students' Needs Procedia Social and Behavior Sciences 2 4507-4512. DOI: https://doi.org/10.1016/j.sbspro.2010.03.721

[10] Saragih E 2014 Designing ESP Material for Nursing Students Based on Need Analysis. International Journal of Linguistic 6 no 4

[11] Lowe I 2009. www.scientificlanguage.com/ esp/needanalysis.pdf Need Analysis
[12] Gay LR, Mills GE, Airasian PW 2012 Educational Research: Competencies for Analysis and Applications (New Jersey: Pearson Education, Inc)

[13] Mackey A, Gass SM 2005 Second Language Research: Methodology and Design (New Jersey: Lawrence Elrbaum Associates Publishers)

[14] Long MH 2005 Second Language Need Analysis (Cambridge:Cambridge University Press)

[15] Mukhaiyar 2017 Pengantar Penelitian Pembelajaran Bahasa Inggris (Padang: Suka Bina Press)

[16] Cresswell JW 2009 Research Design: Qualitative, Quantitative, Mixed Methods Approaches (California: Sage Publications)

[17] Riduwan, Akdon 2016 Belajar Mudah Penelitian Untuk Guru-Karyawan dan Peneliti Pemula (Bandung:Alfabeta)

[18] Robinson P 1991 ESP today:A practicioner's guide (New York:Prentice Hall) 